\title{
The role of low-frequency intraseasonal oscillations in the anomalous Indian summer monsoon rainfall of 2002
}

\author{
S Sajani*, S Naseema Beegum and K Krishna Moorthy \\ Vikram Sarabhai Space Centre, Trivandrum 695 022, India. \\ *e-mail: sajanirajendran@yahoo.com
}

\begin{abstract}
We analyze the dynamical features and responsible factors of the low-frequency intraseasonal time scales which influenced the nature of onset, intensity and duration of active/break phases and withdrawal of the monsoon during the anomalous Indian summer monsoon of 2002 - the most severe drought recorded in recent times. During that season, persistent warm sea surface temperature anomalies over the equatorial Indian Ocean played a significant role in modulating the strength of the monsoon Hadley circulation. This in turn affected the onset and intense break spells especially the long break during the peak monsoon month of July. Strong low-frequency intraseasonal modulations with significant impact on the onset and active/break phases occurred in 2002 which were manifested as a good association between low-frequency intraseasonal oscillations and the onset and active/break spells. Further, SST anomalies over the equatorial Indo-Pacific region on low-frequency intraseasonal time scales were found to affect the equatorial eastward and thereby off-equatorial northward propagations of enhanced convection over the Indian region. These propagations in turn modulated the active/break cycle deciding the consequent severity of the 2002 drought.
\end{abstract}

\section{Introduction}

Fluctuations in monsoon rainfall have a decided impact on the society and economy of monsoon countries. In spite of the remarkable consistency in the seasonal reversal of the large-scale circulation features associated with monsoon, the Indian summer monsoon rainfall (ISMR) exhibits considerable interannual variability. Some of this variability of the monsoon can be related to ENSO where the enhanced convection associated with warm sea surface temperature (SST) anomalies in equatorial eastern Pacific can induce anomalous subsidence of Walker circulation over the Indian region and thereby suppress monsoon rainfall (Sikka 1980; Palmer et al 1992; Sikka 2003). However, there appear to be modulations that occur independently of ENSO extrema (e.g., 1979, 1986, and 1994), particularly noteworthy is the recent abnormally low ISMR in 2002 (Sikka 2003; Kalsi et al 2004). This most severe drought season recorded in recent times (with rainfall about 19\% below the long term all-India normal) was associated with only a weak, warm SST anomaly developing in the central Pacific during the latter half of the season. Apart from the anomalously low seasonal rainfall, the remarkably different nature of the onset and subseasonal evolution of the monsoon during this year are compelling reasons for undertaking this study.

Many studies have investigated the possible causes for the 2002 drought over India (e.g., Gadgil et al 2002, 2003; Bhat 2003; Sikka 2003; Kalsi et al 2004; Narayanan et al 2004; Srivastava et al 2004). Many contributing planetary scale factors which developed close to the region, almost simultaneously with the evolution of 2002 monsoon were suggested as possible causes for the 2002 July

Keywords. Indian summer monsoon rainfall; false onset; low-frequency intraseasonal oscillations; NPISO, Madden-Julian Oscillation. 
break and the consequent seasonal monsoon deficit. These were:

- the persistent wave-like pattern over Eurasia with a trough in the middle and upper troposphere over the Caspian Sea-Aral Sea region which exerted influence over northwest India leading to persistent subsidence over northwest India and the adjoining Arabian Sea,

- southward shift of the Mascarene high and

- eastward anchoring of organised convection over the NW Pacific (Sikka 2003; Kalsi et al 2004).

Among these, the third factor caused an eastward shift in the genesis of tropical storm/typhoon activity and northward steering of their tracks. These factors weakened the monsoon on the one hand by preventing their remnants reaching the Bay of Bengal for a possible revival there, or on the other hand by inducing subsidence over the adjacent Indian region. Gadgil et al (2003) examined the simultaneous relationship between equatorial Indian Ocean and Indian summer monsoon rainfall. They showed that every monsoon season with excess rainfall/drought during 1979-2002 can be explained in terms of the favourable/unfavourable phase of EQUINOO (Equatorial Indian Ocean Oscillation, defined as the oscillation in surface zonal wind anomalies between west and east equatorial Indian Ocean). Bhat (2006) suggested that the major July 2002 break was associated with persistent and strong multiple inversions due to the prevalence of the air of desert origin, over the eastern Arabian Sea and the west coast of India.

In addition to the large-scale forcings, significant modulations occur on intraseasonal time scales due to internal variability of the Indian summer monsoon system (Goswami 1998). This intraseasonal variability plays a major role in the evolution of monsoon, of which the low-frequency component is the dominant factor in deciding seasonal monsoon rainfall. During 2002, the low-frequency component of intraseasonal variability in the range of 20-60 days was found to be much stronger than other intraseasonal modes such as 10-20 days (Narayanan et al 2004; Sabade et al 2006; Saith and Slingo 2006). In this study we investigate the nature of the prominent low-frequency intraseasonal oscillations (hereafter referred to as 'ISO') during the drought of 2002 , and their contribution in modulating the evolution of the 2002 summer monsoon rainfall. In particular, this study focuses on the role of the northward propagating ISO (NPISO, Sikka and Gadgil 1980) and its global component associated with the Madden-Julian Oscillation (MJO, Madden and Julian 1994) in the 2002 monsoon and the connection between their

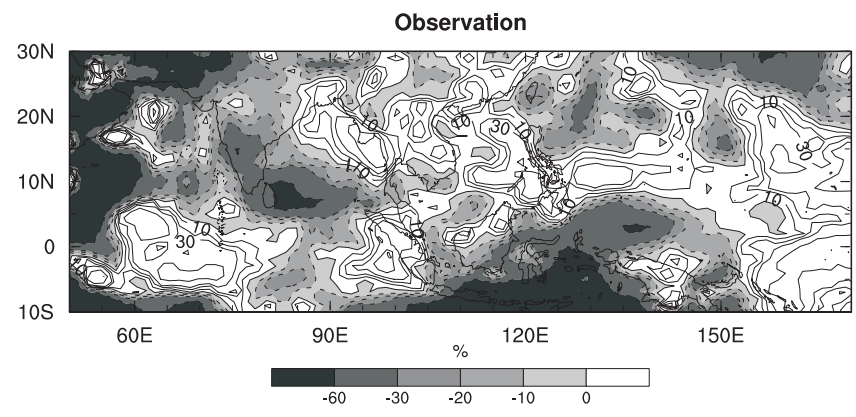

Figure 1. 2002 JJAS mean rainfall departure as percentage of climatological JJAS mean based on TRMM 3B42 rainfall.

phases and the onset and active/break spells of the 2002 Indian summer monsoon. For the analysis we made use of the recent TRMM based datasets with the objective of assessing their utility for tropical ISO studies.

The datasets used for the analysis are described in section 2. The observed features of 2002 Indian summer monsoon and the role played by ISO are discussed in section 3. Concluding remarks are given in section 4 .

\section{Datasets}

We make use of data from the microwave radiometer onboard the Tropical Rainfall Measuring Mission (TRMM) satellite. For the analysis of 2002 monsoon rainfall, daily 3B42 TRMM-adjusted merged-infrared precipitation (Version 5) since 1998 (Adler et al 2000) is used. For computing the long-term daily mean data used in figures 1 and 3 , a combined data set of daily rainfall estimates interpolated from Global Precipitation Climatology Project (GPCP) pentad precipitation data for the period 1979-1997 (Xie et al 2003) and daily TRMM 3B42 data at $1^{\circ} \times 1^{\circ}$ resolution are used. The other TRMM Microwave Imager (TMI) data used in this study are 3-day running means of surface wind speed derived using $11 \mathrm{GHz}$ radiometer channel (http://trmm.gsfc.nasa.gov). In addition, daily NCEP/NCAR reanalysis datasets (Kalnay et al 1996), daily SSTs interpolated from 19822002 Reynold's weekly SSTs (Reynolds et al 2002) and monthly NOAA OI.v2 SST datasets (Reynolds and Smith 1994) are also used. Daily raingauge observations over the Indian landmass based on COLA GTS data (http://www.monsoondata.org) for the period 1979 to 15 September 2002 is also used.

\section{Indian summer monsoon of 2002}

The abnormal Indian summer monsoon of 2002 is the most severe drought recorded in recent times 


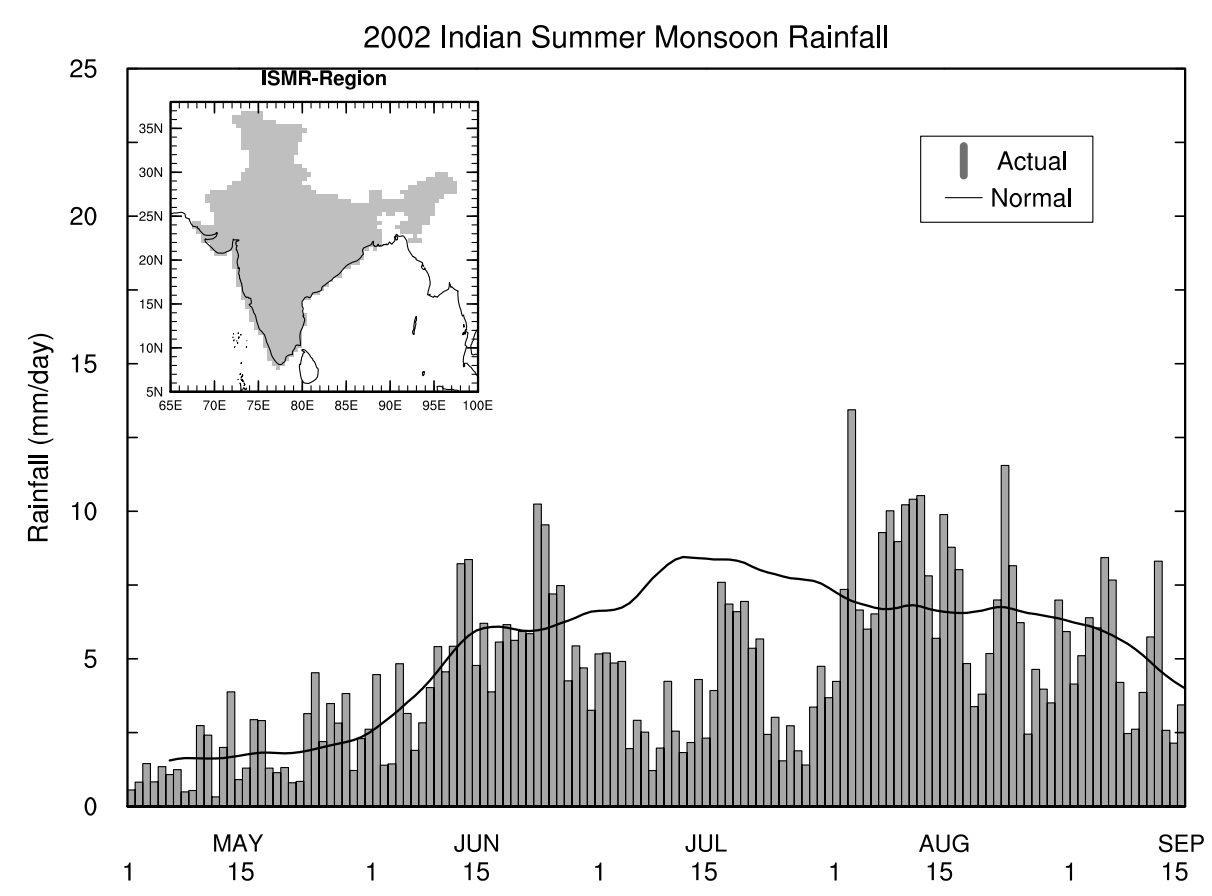

Figure 2. Daily all-India (region highlighted in the inset map) average rainfall from COLA GTS data during 2002 summer season. Daily long term mean is represented by the solid line.

with the observed rainfall about $19 \%$ below the long term all-India normal. Here, we present a detailed analysis of this severe drought monsoon and its contributing factors on intraseasonal time scales.

Observed June-July-August-September (JJAS) mean rainfall departure during 2002 based on TRMM 3B42 rainfall shows that severe drought conditions prevailed over most of the Indian subcontinent with large areas in western India and southern peninsula where the monsoon rainfall was deficient by more than $30 \%$ of the normal (figure 1). At the same time of widespread decrease of seasonal monsoon rainfall over land, the equatorial Indian Ocean (EQIO) experienced intense rainfall anomalies more than $20 \%$ of normal extending longitudinally across most of the ocean basin. The maximum value of the anomaly over $60^{\circ} \mathrm{E}-75^{\circ} \mathrm{E}$ around the equator is close to $50 \%$.

Daily variation of the 2002 all-India summer monsoon rainfall (figure 2) based on COLA GTS data comprising raingauge estimates over the Indian landmass (highlighted in the inset India Map), distinctly shows the special nature of the onset and evolution of monsoon during the 2002 summer season. A notable aspect of 2002 season is the special onset (Ananthakrishnan and Soman 1988; Joseph et al 1994; Flatau et al 2003) where the false onset occurs around 11 May with mild and intermittent rainfall continuing until around 28 May. The region experiences a dry spell afterwards which results in a late onset of bountiful monsoon rains over India compared to the climatological onset date in the end of May/beginning of June. The real onset of rainfall occurs around mid-June that persists until the last week of June. Unlike during the false onset, associated with the real onset, the low-level jet (LLJ) reaches sufficient strength to provide sustained cross-equatorial flow of moist air which is seen typically associated with the actual monsoon onset. The sustained seasonality in monsoon regional components such as LLJ and the monsoon Hadley circulation associated with the real onset will be discussed subsequently. The primary feature of the season is the intense and long dry spell extending from the end of June until the beginning of August.

The large-scale variation of ISMR is associated with fluctuations in rainfall over the monsoon convergence zone (MCZ) coinciding with the mean location of seasonal trough over India (Sikka 1980; Gadgil 2003). The variation in rainfall over the MCZ is closely related to active and break phases characterized by enhanced and reduced precipitation over central and northern India with associated changes in large-scale circulation. The daily normalized anomalies of rainfall averaged over central India $\left(15^{\circ} \mathrm{N}-25^{\circ} \mathrm{N} ; 75^{\circ} \mathrm{E}-85^{\circ} \mathrm{E}\right.$, coinciding the $\mathrm{MCZ})$ and EQIO $\left(10^{\circ} \mathrm{S}-5^{\circ} \mathrm{N} ; 50^{\circ} \mathrm{E}-\right.$ $\left.100^{\circ} \mathrm{E}\right)$ shows all the major characteristics of 2002 season viz., the double onset, intense break in July, and the early withdrawal of monsoon (figure 3). 


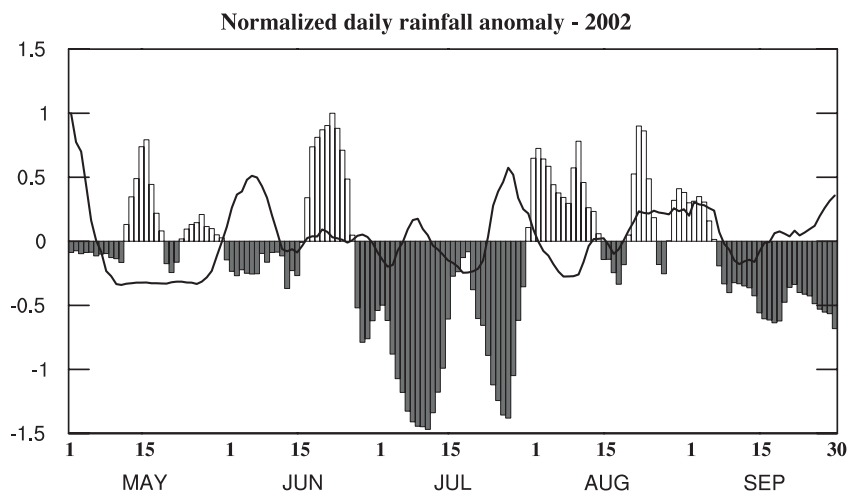

Figure 3. Normalized daily rainfall anomalies during 2002 summer season based on TRMM 3B42 rainfall data. The bars represent average over the central Indian region (MCZ) and the line represents average over the equatorial Indian Ocean (EQIO).

The false onset occurs in mid-May with mild and intermittent rainfall continuing until the beginning of June. The region experiences a dry spell afterwards with the real onset of rainfall occurring in the middle of June and continuing up to the last week of June. This results in a late onset of bountiful monsoon rains over India compared to the climatological onset date in the beginning of June. It can be seen that there is an intense and long dry spell extending from the end of June until the beginning of August. Finally the season experiences an early withdrawal of monsoon due to a long break spell extending from the second week of September. These active/break phases over the MCZ have been consistent with the 2002 ISMR daily variation entirely based on the in situ rainfall over Indian stations (figure 2, and also with the corresponding variation based on IMD dataset available at http://www.tropmet.res.in). A notable feature in figure 3 is the near-inverse rainfall variation between $\mathrm{MCZ}$ and $\mathrm{EQIO}$ where increased (decreased) rainfall over EQIO coincides with decreased (increased) rainfall over the MCZ throughout most of the summer season. This can be understood in terms of the modulations in the two limbs of the reverse Hadley cell (monsoon cell) with one on the warm equatorial Indian Ocean and the other over the heated continent in the north.

\subsection{Role of equatorial SST}

The mean SST departure during the peak monsoon months of July and August of 2002 (figure 4, based on Reynold's monthly OI SST) shows that the entire equatorial Indian Ocean was anomalously warm with anomalies stronger than that over the west Pacific Ocean. These anomalies over regions with warm mean SSTs (greater than the

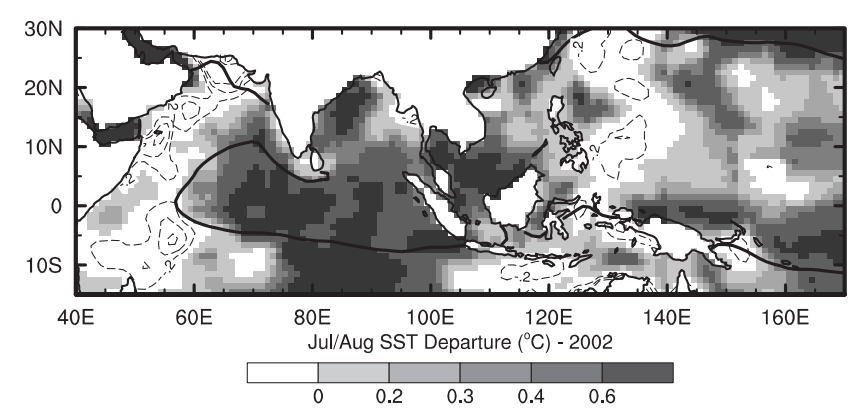

Figure 4. July-August mean SST anomaly (positive: shaded; negative: dashed contours) in 2002. Solid line highlights the region with climatological July-August mean SST greater than $28^{\circ} \mathrm{C}$.

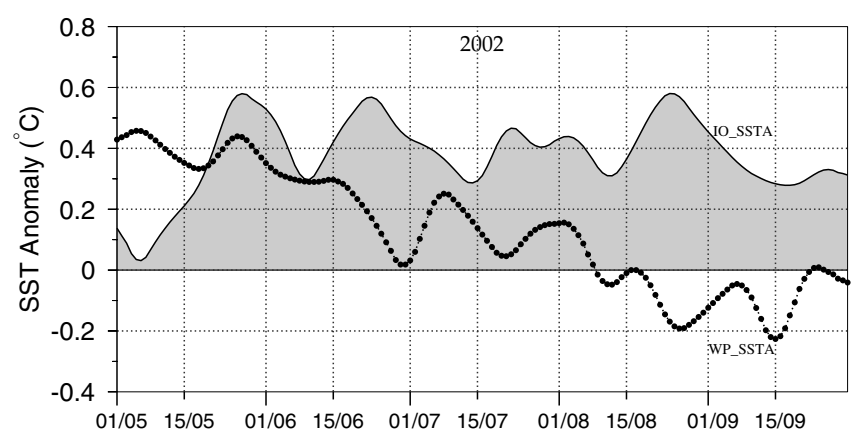

Figure 5. SST anomalies averaged over equatorial Indian Ocean (denoted as IO_SSTA) and western Pacific (denoted as WP_SSTA) during 2002.

basin threshold value of $\sim 28^{\circ} \mathrm{C}$ for the commencement of organized convection, Gadgil et al (1984) are important and can modulate the meridional land-ocean temperature contrast and the local Hadley circulation resulting in increased ascent (descend) and convection (subsidence) over the equatorial Indian Ocean (Indian subcontinent). On the seasonal mean time scale, observational (Krishnan et al 2003) and sensitivity studies based on idealized Indian Ocean SST anomalies (Chandrasekar and Kitoh 1998) suggest that rainfall increased (decreased) over the equatorial Indian Ocean domain of warm (cold) SST anomaly. This was found to be associated with anomalous negative (positive) rainfall departures on the seasonal time-scale over the Indian land region accompanied by the weakening (strengthening) of the cross equatorial flow and local Hadley circulation.

The normalized daily SST anomalies (interpolated from Reynold's weekly SSTs) averaged over EQIO and western Pacific warm pool region (5S$5 \mathrm{~N} ; 120-160 \mathrm{E})$ also show that in spite of subseasonal fluctuations, the warm SST anomalies persisted over EQIO throughout the season (figure 5). To understand the mechanisms responsible for sustaining this persistent warmer anomalies 
(a)

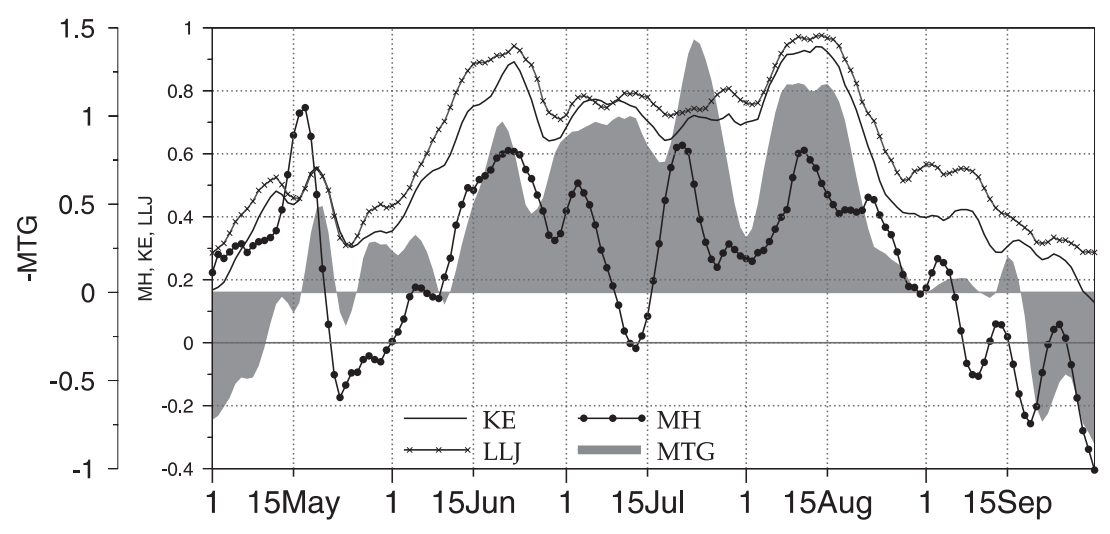

(b)

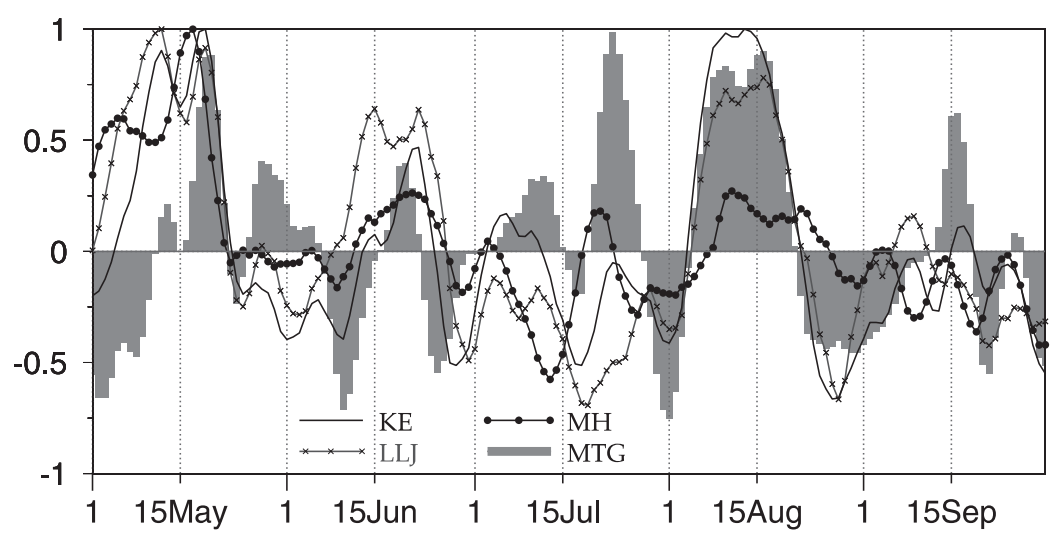

Figure 6. Daily (normalized and then 5-day running mean applied) (a) time series of different monsoon indices and (b) time series of anomalies of different monsoon indices during 2002 Indian summer monsoon season.

throughout the season, the role of the developing El Niño and surface and subsurface ocean circulation needs to be investigated in detail. These anomalies were larger than the anomalies over west Pacific especially in later months of the season when weak warm El Niño anomalies started developing in the central Pacific. This can impact both the local Hadley circulation over the Indian sector and the Walker circulation along the Asia-Pacific sector resulting in the equatorial Indian Ocean having an anomalously stronger convection compared to Indian landmass and west Pacific warm pool regions (figure 1 ).

\subsection{Subseasonal variation}

It is known that the duration and strength of break spells in a certain year are important in deciding the seasonal mean rainfall anomaly during that year (Krishnamurti and Bhalme 1976). In addition, the majority of the years that experienced double onset has been found to be associated with below normal rainfall (Flatau et al 2001). Thus, the occurrence of long and intense break spells and a double onset over India assumes great significance in deciding the seasonal anomaly during 2002. Therefore, it is pertinent to examine the subseasonal time-scale response of convection to this persistent SST anomaly over the Indian Ocean. Also a consistent understanding of the relationship between the EQIO SST anomalies and ISO variability in convection is thus essential for interpreting the intense break spells particularly in the peak monsoon month of July.

To further understand the fluctuations in monsoon activity within the season, different monsoon indices that reflect the intraseasonal circulation changes, are analyzed. For this, a monsoon circulation index (MH, Goswami et al 1999, based on the strength of the local Hadley cell created by the off equatorial monsoon heating, is defined as the shear between 850 and 200-hPa meridional winds averaged over $10^{\circ} \mathrm{N}-30^{\circ} \mathrm{N} ; 70^{\circ} \mathrm{E}-110^{\circ} \mathrm{E}$ ), the kinetic energy of the surface winds (KE) averaged over $5^{\circ} \mathrm{N}-20^{\circ} \mathrm{N} ; 40^{\circ} \mathrm{E}-110^{\circ} \mathrm{E}$, the strength of cross-equatorial flow associated with the lowlevel Somali jet (LLJ) based on the $850-\mathrm{hPa}$ wind speed averaged over $5^{\circ} \mathrm{N}-20^{\circ} \mathrm{N} ; 50^{\circ} \mathrm{E}-80^{\circ} \mathrm{E}$ and 
the meridional temperature gradient index (MTG, Kawamura 1998, based on the difference in areaaveraged upper tropospheric $(500-200 \mathrm{hPa})$ thickness between the Tibetan Plateau $\left(20^{\circ} \mathrm{N}-40^{\circ} \mathrm{N}\right.$; $\left.50^{\circ} \mathrm{E}-100^{\circ} \mathrm{E}\right)$ and the Indian Ocean $\left(0^{\circ} \mathrm{N}-20^{\circ} \mathrm{N}\right.$; $\left.50^{\circ} \mathrm{E}-100^{\circ} \mathrm{E}\right)$ regions) are used.

Actual and normalized (with respect to the daily long term mean over the last 30-year period) anomalies of these indices (figure 6a and b) show the close relationship between subseasonal variation of large-scale circulation and that of the monsoon rainfall (figure 3). The peaks of the indices in mid-May corresponds to the false onset and the peaks in mid-June corresponds to the real onset. The weakening of large-scale monsoon circulation parameters during July till the beginning of August corresponds to the intense break spell and the revival afterwards coincides with the short active spell in the first week of August. The indices show weakening of large-scale monsoon circulation after the first week of September and the commencement of the next intense break spell results in an early withdrawal of monsoon. One notable aspect is the pronounced fluctuations in MH, LLJ and KE and to some extent in MTG that are markedly consistent with the MCZ rainfall fluctuations. These variations indicate significant subseasonal modulations in the local Hadley circulation. Another notable aspect is the difference in actual monsoon indices between the false and real onset phases (figure 6a). Unlike during the false onset phase, the actual indices show a sharp and sustained strengthening of the indices associated with the real onset until the withdrawal. Whereas, during the false onset, the indices do not show a sustained increase in amplitudes which indicates the absence of organized seasonal changes in all forcing factors of monsoon.

\section{2a Northward Propagating Intraseasonal Oscillations (NPISO)}

The dominant mode of monsoon low-frequency intraseasonal variation that is associated with the onset and active-break spells over the Indian region is the northward propagating ISO (NPISO, Sikka and Gadgil 1980; Gadgil 2003). NPISOs comprise successive 30-40-day time-scale northward propagations of organized convection in summer over the Asia-west Pacific sector (Yasunari 1979; Sikka and Gadgil 1980; Srinivasan and Smith 1996). The time-latitude variation of 20-80-day band pass filtered (following Duchon 1979) TRMM 3B42 rainfall and TMI surface winds averaged over Indian longitudes (figure 7) shows the close relationship between propagating signals of active convection and the onset, active and break phases and withdrawal of monsoon. The false onset was

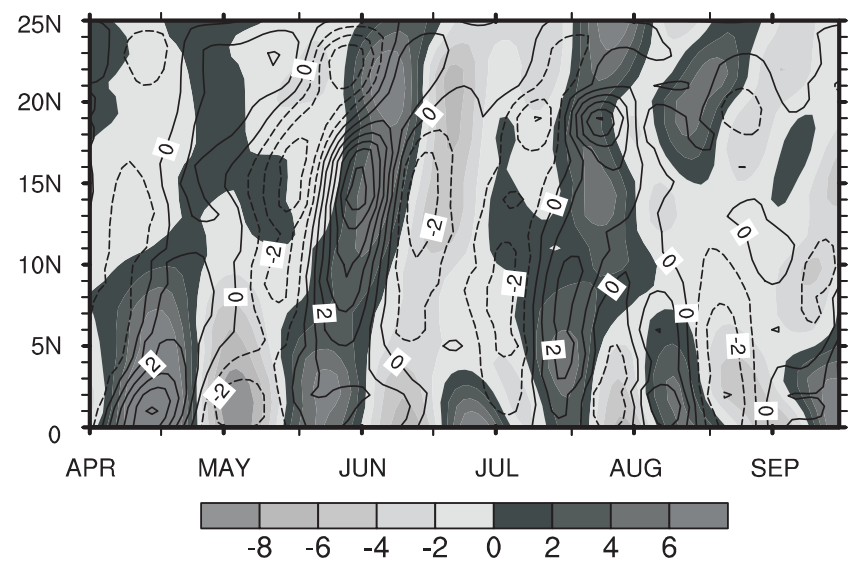

Figure 7. Time-latitude variation of 20-80-day filtered TRMM 3B42 rainfall anomalies averaged over $75^{\circ} \mathrm{E}-85^{\circ} \mathrm{E}$ (shaded) and filtered TMI surface zonal wind speed anomalies (contours) averaged over western Indian Ocean $\left(50^{\circ} \mathrm{E}-80^{\circ} \mathrm{E}\right)$.

characterized by a propagating rainbelt from the equatorial Indian Ocean reaching the southern peninsula in the middle of May. A later real onset of heavy precipitation over India by the middle of June coincides with the next propagating anomaly reaching the central Indian latitudes. The intense break spell during July and after the first week of September resulting in an early withdrawal are associated with prolonged periods of suppressed convection and absence of any active propagations. The enhancement (weakening) of the cross equatorial flow that is a measure of the strength of local Hadley circulation and the large-scale monsoon leads the propagating convective (non-convective) anomalies. This shows that the evolution of the monsoon and fluctuations in ISMR during 2002 were strongly associated with variations in cross equatorial flow.

\section{2b Madden-Julian Oscillation (MJO)}

Due to the significant role of NPISOs on monsoon, several studies have attempted to address the responsible mechanism behind NPISOs (e.g., Goswami and Shukla 1984; Nanjundiah et al 1992; Wang and Xie 1997). Some of these studies suggest that NPISOs are closely related to the eastward propagations associated with the MJO (e.g., Krishnamurti and Subrahmanyam 1982; Wang and Rui 1990; Wang and Xie 1997; Rajendran and Kitoh 2006). Wang and Xie (1997) used an intermediate model to show that the northward propagations over the Indian region are caused by emanation of the moist Rossby waves over maritime continents of west Pacific. The emanation occurs when coherent equatorial MJO propagation as a coupled Kelvin-Rossby wave packet attenuates over the Maritime Continent due to decreased moist 
(a)

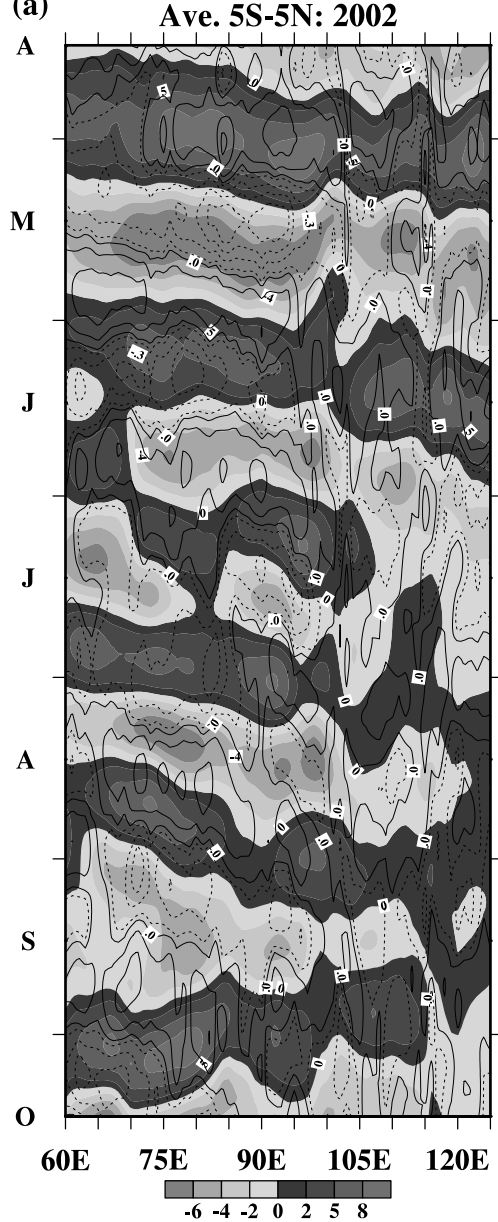

(b)

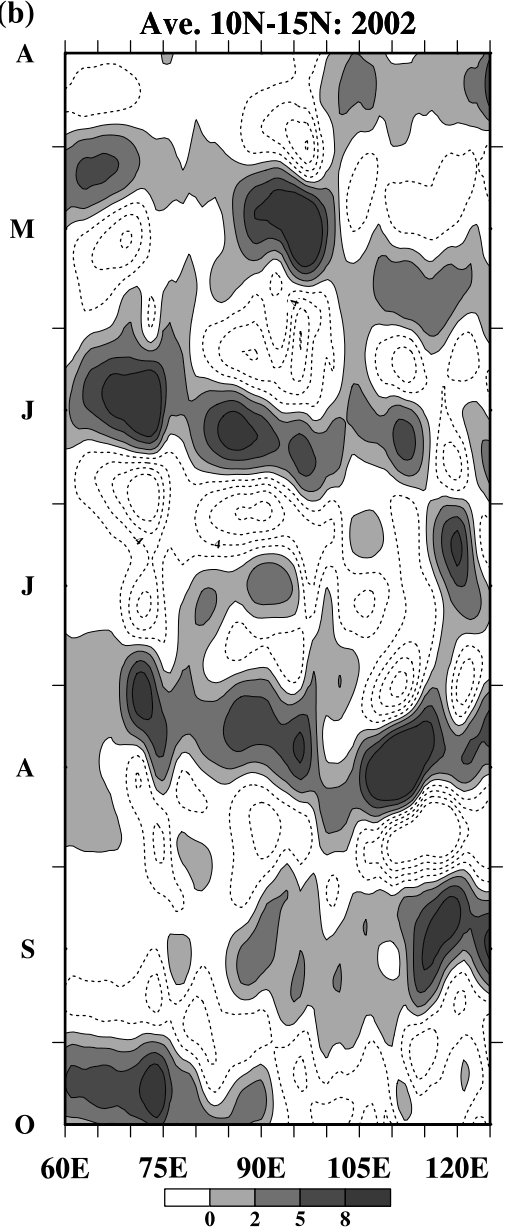

Figure 8. (a) Time-longitude variation of 20-80-day filtered TRMM 3B42 rainfall and filtered SST (contour) anomalies averaged over the equator $\left(5^{\circ} \mathrm{S}-5^{\circ} \mathrm{N}\right)$ and (b) filtered observed rainfall averaged over the off-equatorial region $\left(10^{\circ} \mathrm{N}-15^{\circ} \mathrm{N}\right)$.

static energy stored in the boundary layer. Hence, the fact that the NPISOs in the Indian sector are one aspect of the equatorial eastward moving Kelvin-Rossby wave packet will be reflected in the eastward propagation of the off-equatorial convection (Lawrence and Webster 2002; Rajendran and Kitoh 2006). Figure 8 shows the time-longitude variation of (a) 20-80-day filtered anomalies of rainfall (shades) and SST (contour) averaged over the equator $\left(5^{\circ} \mathrm{S}-5^{\circ} \mathrm{N}\right)$ and (b) filtered rainfall averaged over the off-equatorial region $\left(10^{\circ} \mathrm{N}-15^{\circ} \mathrm{N}\right)$. Consistent with the hypothesis of Wang and Xie (1997), coherent MJO propagations reaching the maritime continents of the western Pacific (figure 8a) lead to later off-equatorial eastward propagations over the Indian region (figure $8 \mathrm{~b}$ ) which in turn are associated with subsequent NPISOs (figure 7) over the north Indian Ocean coinciding with the active and break spells of ISMR. Thus, the evolution of MJO activity during the summer of 2002 (figure 8) provides important forecasting clues about the onset and break spells. For example, the development of false onset depended on the timing of intraseasonal oscillation (ISO) in the Indian Ocean and the propagation of convective episodes into the western Pacific. The false onset in 2002 was initiated by the northward motion of equatorial convection related to the ISO that developed in the Indian Ocean in early May.

The SSTs and coupled air-sea interaction are found to be crucial for both equatorial MJO and NPISO propagations (Rajendran and Kitoh 2006). On intraseasonal time scales, SSTs are found to have a coherent phase relationship with convection where warm (cold) SSTs lead (lag) enhanced convection by about a week (figure 8a). In addition to the fact that tropical ISOs evolve through coherent air-sea convective intraseasonal interaction among SST, convection and surface fluxes, the SST is also modulated with significant impact from convection through a coupled feedback process on intraseasonal time scales over the Indian and west Pacific Oceans. Thus, as the ISO propagated eastward to the western Pacific, intense convection feedbacks to cool off the SSTs that inhibit further convection till the next SST warming phase 
is invigorated by suppressed convection. The short dry spell after the false onset is led by cooler intraseasonal SSTs and the real onset lags the next warm SST propagation. The next MJO propagation lags a propagating warm SST signal eastward into the west Pacific with slightly faster speed over the western Pacific. Corresponding to the prolonged break conditions over India in July and September, there are signals of aborted MJO propagations over the eastern Indian Ocean. Their advancement into the western Pacific is terminated by the negative intraseasonal SST anomalies over the west Pacific which may have also been associated with the developing El Niño condition. Due to their failure to progress further eastward, these aborted events do not result in the northward advancement of convection over the Indian sector (figure 8b) and absence of active NPISO over north Indian Ocean. Consequently, the absence of NPISO propagations across the Indian longitudes (figure 7) favours break condition over India. During these periods, the persistent warm SST anomalies over Indian Ocean (figures 6 and 8a) result in intense convection over the equatorial Indian Ocean (figures 3 and $8 \mathrm{a}$ ). This reveals the significant role of equatorial waves on the onset and break spells during 2002 and the influential role played by SST anomalies over equatorial Indian Ocean. Analysis of other recent extreme years (e.g., 2000) also indicates that the propagations associated with equatorial MJO combined with the evolution of SST anomalies over equatorial warm oceans can give important forecasting leads about the real onset of rainfall in the case of a false onset and the dry spells over India in advance.

\section{Conclusions}

The dynamical features and contributing factors responsible for the evolution of monsoon during the anomalous season of 2002 reveal the significant roles played by equatorial intraseasonal wave activity in deciding the onset and active/break spells and SST anomalies over the equatorial Indian Ocean. Further, the intraseasonal SST anomalies over the entire warm equatorial oceans of the AsiaPacific region significantly modulate the MJO propagations which in turn feedback into the NPISO propagations and impact the onset and break phases deciding the consequent severity of drought over India.

\section{Acknowledgements}

The authors are grateful to Prof. R Sridharan, SPL, for his encouragement and valuable suggestions. The first author thanks Dr. T Nakazawa,
MRI for his critical comments and suggestions throughout this study. We appreciate the comments and suggestions from two anonymous reviewers which were helpful in improving the paper.

\section{References}

Adler R F, Huffman G J, Bolvin D T, Curtis S and Nelkin E J 2000 Tropical rainfall distributions determined using TRMM combined with other satellite and rain gauge information; J. Appl. Meteor. 39 2007-2023.

Ananthakrishnan R and Soman M K 1988 The onset of south-west monsoon over Kerala: 1901-1980; J. Climatol. 8 283-296.

Bhat G S 2003 Convection inhibition energy of the inversion and the suppressed rainfall observed over the Arabian Sea during July 2002; Proc. ARMEX Workshop NIOT Chennai, pp 33.

Bhat G S 2006 Indian drought of 2002 - a subseasonal phenomenon?; Quart. J. Roy. Meteor. Soc. 132 2583-2602.

Chandrasekar A and Kitoh A 1998 Impact of localized sea surface temperature anomalies over the equatorial Indian Ocean on the Indian summer monsoon; J. Meteor. Soc. Japan 76 841-853.

Duchon C E 1979 Lanczos filtering in one and two dimensions; J. Appl. Meteor. 18 1016-1022.

Flatau M K, Flatau P J and Rudnick D 2001 The dynamics of double monsoon onsets; J. Climate 14 4130-4146.

Flatau M K, Flatau P J, Schmidt J and Kiladis G N 2003 Delayed onset of the 2002 Indian monsoon; Geophys. Res. Lett. 30(14) 1768 doi:10.1029/2003GL017 434.

Gadgil S 2003 The Indian monsoon and its variability; Ann. Rev. Earth Planet. Sci. 31 429-467.

Gadgil S, Joseph P V and Joshi N V 1984 Oceanatmospheric coupling over monsoonal regions; Nature 312 141-143.

Gadgil S, Srinivasan J, Nanjundiah R S, Krishna Kumar K, Munot A A and Rupa Kumar K 2002 On forecasting the Indian summer monsoon: the intriguing season of 2002; Curr. Sci. 83 294-303.

Gadgil S, Vinayachandran P N and Francis P A 2003 Droughts of the Indian Summer Monsoon: Role of clouds over the Indian Ocean; Curr. Sci. 85 1713-1719.

Goswami B N 1998 Interannual variations of Indian summer monsoon in a GCM: External conditions versus internal feedbacks; J. Climate 11 501-522.

Goswami B N and Shukla J 1984 Quasi-periodic oscillations in a symmetric general circulation model; J. Atmos. Sci. $4120-37$.

Goswami B N, Krishnamurthy V and Annamalai H 1999 A broad-scale circulation index for the interannual variability of the Indian summer monsoon; Quart. J. Roy. Meteor. Soc. 125 611-633.

Joseph P V, Eischeid J K and Pyle R J 1994 Interannual variability of the onset of the Indian summer monsoon and its association with atmospheric features, El Niño and sea surface temperature anomalies; J. Climate $\mathbf{7}$ 81-105.

Kalnay E and Co-authors 1996 The NCEP/NCAR 40year reanalysis project; Bull. Amer. Meteor. Soc. 77 437-471.

Kalsi S R, Hatwar H R, Jayanthi N, Subramanian S K, Shyamala B, Rajeevan M and Jenamani R K 2004 Various aspects of unusual behaviour for monsoon 2002; IMD. Met. Monograph Syn. Met. 2/2004, pp 105. 
Kawamura R 1998 A possible mechanism of the Asian summer monsoon-ENSO coupling; J. Meteor. Soc. Japan 76 1009-1027.

Krishnamurti T N and Bhalme H N 1976 Oscillations of a monsoon system. Part I. Observational aspects; J. Atmos. Sci. 33 1937-1954.

Krishnamurti T N and Subrahmanyam D 1982 The 30-50 day mode at $850 \mathrm{mb}$ during MONEX; J. Atmos. Sci. 39 2088-2095.

Krishnan R, Mujumdar M, Vaidya V, Ramesh K V and Satyan V 2003 The abnormal Indian summer monsoon of 2000; J. Climate 16 1177-1194.

Lawrence D M and Webster P J 2002 The boreal summer intraseasonal oscillation: Relationship between northward and eastward movement of convection; J. Atmos. Sci. 59 1593-1606.

Madden R A and Julian P R 1994 Observations of the 40-50 day tropical oscillation - A review; Mon. Wea. Rev. 122 814-837.

Nanjundiah R S, Srinivasan J and Gadgil S 1992 Intraseasonal variation of the Indian summer monsoon. II: Theoretical aspects; J. Meteor. Soc. Japan 70 529-550.

Narayanan M S, Rao B M, Shivani Shah V S, Prasad and Bhat G S 2004 Role of atmospheric stability over the Arabian Sea and the unprecedented failure of monsoon 2002; Curr. Sci. 86 938-947.

Palmer T, Brankovic C, Viterbo P and Miller M J 1992 Modeling interannual variations of summer Monsoons; $J$. Climate 5 399-417.

Rajendran K and Kitoh A 2006 Modulation of tropical intraseasonal oscillations by ocean-atmosphere coupling; J. Climate 19 366-391.

Reynolds R W and Smith T M 1994 Improved global sea surface temperature analysis using optimum interpolation; J. Climate 7 929-948.

Reynolds R W, Rayner N A, Smith T M, Stokes D C and Wang W 2002 An improved in situ and satellite SST analysis for climate; J. Climate 15 1609-1625.
Sabade S S, Kulkarni A and Kripalani R H 2006 Intraseasonal oscillations during contrasting monsoons; Proc. Natl. Conf. ATMOCIN.

Saith N and Slingo J M 2006 The role of the Madden-Julian Oscillation in the El Niño and Indian drought of 2002; J. Climate 26 1361-1378.

Sikka D R 1980 Some aspects of the large scale fluctuations of summer monsoon rainfall over India in relation to fluctuations in planetary and regional scale circulation parameters; Proc. Indian Acad. Sci. (Earth 85 Planet. Sci.) 89 179-195.

Sikka D R 2003 Evaluation of monitoring and forecasting of summer monsoon over India and a review of monsoon drought of 2002; Proc. Indian Natn. Sci. Acad. 69 A(5) 479-504.

Sikka D R and Gadgil S 1980 On the maximum cloud zone and the ITCZ over Indian longitudes during the southwest monsoon; Mon. Wea. Rev. 108 1840-1853.

Srinivasan J and Smith G L 1996 Meridional migration of tropical convergence zones; J. Appl. Meteor. 35 1189-1202.

Srivastava A K, Rajeevan M and Kshirasagar S R 2004 Role of ITCZ over north Indian Ocean and pre-Meiyu front in modulating July rainfall over India; J. Climate 17 673-678.

Wang B and Rui H 1990 Dynamics of the coupled moist Kelvin-Rossby wave on an equatorial $\beta$-plane; J. Atmos. Sci. 47 397-413.

Wang B and Xie X 1997 A model for the boreal summer intraseasonal oscillation; J. Atmos. Sci. 54 72-86.

Xie P, Janowiak P A, Arkin R, Gruber A, Ferraro R, Huffman G J and Curtis S 2003 GPCP pentad precipitation analyses: An experimental data sets based on gauge observations and satellite estimates; J. Climate 16 2197-2214.

Yasunari T 1979 Cloudiness fluctuations associated with the Northern Hemisphere summer monsoon; J. Meteor. Soc. Japan $57227-242$. 